\title{
Constitutional Protection for Crime Victims and Witnesses in Indonesia and Its Problems
}

\author{
JOHN KENEDI \\ Law Faculty of Post-Graduate of IAIN Bengkulu, \\ Jl. Raden Fatah Pagar Dewa Kec. Selebar Kota Bengkulu, Indonesia \\ correspondence author: johnkenedi297@yahoo.com
}

\begin{abstract}
The constitutional protections toward crime witnesses in Indonesia are indisputably inevitable. As an effort to uphold justice, Indonesia relies on the formal mechanism of criminal law known as the criminal justice system. The system starts from reports by the police, prosecution by the prosecutor, to the stage of a trial in a court, and execution in a prison. Throughout its development, the criminal justice system seemed to focus more on protecting criminal offenses (criminal oriented) rather than paying attention to the rights of witnesses and victims (witness and victim-oriented). Therefore, the studies that concern the rights of witnesses and victims are highly needed in order to figure out ways to balance the treatment between the suspects/defendants and the witnesses and victims. Through the use of the statue approach and conceptual approach, the positions and the rights of legal protection for witnesses and victims are thoroughly captured and described in this current research. Besides, the factors causing uneven attention and unfair treatment toward crime victims are also specifically identified.
\end{abstract}

Keywords: constitutional protection, witnesses, criminal justice

\section{Introduction}

The reforms that occurred in 1998 have given rise to several important agendas for the development of the law in Indonesia. One of the important agendas is the demand toward law enforcement that is equitable, particularly to the Government's efforts in positioning law-determination against community sub-systems. The aim is to make Laws no longer act as sub-ordinations of rival political will where such a case did happen during the New Order government.

The existence of law in society is urgent and crucial since the law acts as a protector of human interest from all disorders and losses caused by legal violations. (Khan, 2012:2).

The independent and equitable law enforcement is expected to realize a safe and secure community order in accordance with the enactment of Law No. 48 the year 2009 article 1 paragraph (1) on judicial authority as follows:

\begin{abstract}
"Judicial power is the power of an independent state to administer the judiciary in order to enforce the law and justice based on Pancasila and the Constitution of the Republic of Indonesia year 1945, for the implementation of the state constitution of Indonesia Republic."
\end{abstract}

The government relies on the criminal law system as one of the instruments to implement just the law. The Criminal Justice System or The Integrated Criminal Justice System is a series of processes that begins with the stages of a preliminary investigation, full investigation, arrest, and detention, to the judicial and penal process. Unfortunately, the ability of criminal law both in terms of formally and its material is still very limited (Kenedi, 2017: 173).

The guarantee of legal protection for the perpetrators has been given starting from the process of preliminary investigation and investigation. One of them is a suspect has the right to have consumption which has been decided by the state as well as

Received: 2020-03-28, Revised: 2020-05-05, Accepted: 2020-06-03

Print ISSN: 0215-8175; Online ISSN: 2303-2499. https://doi.org/10.29313/mimbar.v36i1

Accredited Sinta 2 based on the decree No.10/E/KPT/2019 until 2023. Indexed by DOAJ, Sinta, Garuda, Crossreff, Dimensions 
an opportunity to get legal assistance once the detention is carried out. In addition, the offender is also given the right to deny the judge and the right not to accept court decisions in the form of resistance (i.e. appeal and cassation) and the right to Review/PK (see Article 1 paragraph [12] of the Criminal Procedure Code). Furthermore, what makes this problem more interesting is when the perpetrators have been sent to jail, they even receive attention and facilities including bed, food, medical care, education, and job training, and get psychological assistance (Angkasa, 2008: 34). In various parts of the world, the issue of the guarantee for legal protection and social protection of witnesses and victims is an interesting problem to be observed (Welch, 2011: 3). The weak rules of law in anticipating and accommodating the protection of witnesses and victims indicate that such issues are thoroughly unraveled and thus, they remain blunt protection (Ismail, 2016: 6). Consequently, the law that is supposed to create justice is finally questioned.

Anthony J. Schembry argued that "crime actually has three dimensions, namely: criminals (criminal actors) and victims of crime (victims)." (Atmasasmita, 1992: 2). Therefore, the guidelines to prosecute the criminal cases become a study as well as a benchmark for various activities of law enforcers, both for the police as investigators, prosecutors as public prosecutors, including judges as determinants of decisions for perpetrators of crime (Rifai, 1994: 12). In addition, between the perpetrators and victims of crime can actually be likened to two sides of a coin, if there is a crime it can also be ensured there are victims of crime because true crime is a result of interaction. As for the interrelation between phenomena that occur, the perpetrators of crime and victims can function as participants who are actively or passively involved in a crime (Iswanto and Angkasa, 2007: 2). Thus, the enforcement of justice in the formal criminal law mechanism is one of the main tasks of the country.

The phenomenon of criminal law enforcement in Indonesia, which is implemented so far, tends to focus on what the perpetrators have done, especially in the agenda of proving the fulfillment of criminal elements which are then used as the basis in criminal charges (Fuady, 2015: 7). In other words, the perpetrators of crimes are always positioned as the "main characters" of a criminal law event. On the other hand, the attention to witnesses and victims tends to be neglected. For example, in terms of the security of witnesses, services to victims, and the way the legal institutions treat both witnesses and victims. The situation makes the need for a progressive change in the law paradigm (Salman, 2013; 146-147).

Factually, the victim as the one who suffered disadvantages as the results from the crime seems isolated from freedom. Therefore, it is not surprising if the assumption arises that the victim is a party that lacks attention in the criminal justice system, including in the criminal justice system in Indonesia. That fact is in line with Stephen Schafer's phrase "only as 'cinderella' of criminal law" (Mulyadi, 2007: 136).

The equal attention given by law enforcers dealing with perpetrators and victims is something that has become a necessity. Either the perpetrators of crime or the victims of crime must be treated equally between their rights and obligations (Demir, 2018: 21). Specifically, the victims who are actually becoming concrete subjects have thus far received inadequate attention in almost all justice systems in the world (Doak, 2017: 5).

The government can be categorized as indifferent as if they neglect the rights for witnesses and victims when there is no physical and psychological protection given. In this case, the state seems to direct the victims to surrender to face all the circumstances, calamities, and suffering. The victim is forced to accept the reality and must be satisfied with the verdict given to the perpetrators of crime through the mechanism of the criminal legal system despite the fact that the sentence imposed decided by the judge is often felt to be unequal to the victims.

On the basis of the aforementioned reality, the problems that arise are: What is the position and rights of legal protection for victims of crime in the criminal justice system in Indonesia according to Indonesian law? What are the factors causing the equality of attention and treatment that have not been created in the criminal justice system in Indonesia?

This paper aims to identify the position and rights of legal protection for victims of crime in the criminal justice system in Indonesia based on the applicable laws and regulations, as well as to identify the causes of inequal attention and treatment for the 
victims in the justice system. The problematic justice system regarding the witness and victim protection is a theme that the authors have captured as an issue that needs to get space in the discussions upon the academic world, especially in criminal law subjects.

\section{Research Methodology}

This research is normative juridical research or normative indoctrinal law research which focuses on the combination of primary data obtained from the field (field research) and library data (Library Research). The approach used to obtain answers of research questions is the statue approach and the concept approach.

In collecting the legal data, this study uses primary legal material (law), secondary legal material (literature), and tertiary legal materials (dictionaries and websites). The technique that is carried out is documentation studies (library research) that are analyzed in a qualitative normative method. The guideline for the current research is to refer to the works of Soerjono Soekanto and Sri Mamuji regarding normative research methods (Soekanto, 2012: 4).

\section{Results and Discussion}

\section{The Regulation of Legal Protection for Crime Victims Based on Indonesia Penal Code (KUHP)}

In the 1945 Constitution, it is explicitly mentioned that Indonesia is a state which is based on the law (rechtstaat), not a state of power (machstaat). One of the characteristics of a state based on the law system is the existence of guarantees and protection of human rights. So based on its constitution, the Indonesian state is obliged to provide guarantees and protection of the human rights of its citizens, including guarantees of security from crime.

The current level of crime that has been improved significantly has demanded such reforms in the criminal law system in Indonesia. These improvements should not only focus on the perpetrators of crime but must also pay attention to crime victims and witnesses. Hence, the renewal of criminal law (criminal law reform) has now become a "fixed price" for a fundamental change in order to achieve the objectives, action, policy, and criminal punishment (Sulistia and Zurnetti,

\section{2: 1).}

The lack of attention by the government to the protection of witnesses and victims is a very basic problem, especially in the context of the prevailing legal system in our country. Such particular case indicates as if the state was only present in the enforcement of its law, but ignored the efforts to help the crime victims and witnesses that actually deserve protection and forgiveness.

Speaking of the problem regarding the legal protections of witnesses and victims, the government has paid attention to it. It is obviously stated in the enactment of the Indonesia Penal Code as a reference to national criminal law. However, the portion of attention to witnesses and victims is now still considered lacking. The Penal Code does not contain explicit and specific provisions regarding rules of protection for crime victims (Atmasasmita, 1992: 17). The codified book of colonial heritage (Moeljatno, 2015: 17) implies legal protection against victims of crime in Article 14c of the Penal Code. The article states that the judge may set special conditions for the perpetrators of the crime (convicted) to compensate for the loss in whole or in part as a result of the criminal offenses. With regard to the above-mentioned cases, R. Soesilo stated that:

"Implicitly, article 14c paragraph (1) provides protection for victims. The article states; in the command mentioned in article 14a except in the case of fines, with the general agreement thus the convict will not commit an action that can be punished, then the judge may offer a special agreement. That the condemned person will compensate for the losses caused from the action that can be punished in whole or for a part of that which is determined specified to the set up time, which is less than the time of the trial" (R. Soesilo, 1991: 35)

The provisions of Article 14c paragraph (1), Article $14 \mathrm{a}$, and Article 14b imply that the law (as a cumulative policy) mandates the provision of protection to crime victims. Such abstract protection includes penalties that can be imposed by a judge through the determination of general conditions and special conditions, in the form of criminal damages to victims of crime. In this case, the victim has the opportunity to obtain more portion of justice in the form of compensation as a result of deprivation of material rights he/she has. 
The researcher considers that the weakness of the above-mentioned articles is the ill-defined words. It can be seen from the following explanation. First, the cause of the special conditions is only in the form of facultative compensation of which value is actually the authority of the judge (flexible). Second, the phrase "may" in the article is less binding for the judge. The phrase "may" in a legal perspective is certainly very different from the word "can" or "be able to" let alone the word "mandatory". The government's partisanship for victims of crime will only be seen when the phrase "may" is then replaced with the word "mandatory" so that the judge can play an active role in finding substantive justice. Third, the phrase "may" indicate that the fate of the victim is determined solely by the judge's subjective judgment and this condition is not in accordance with the values of restorative justice which is currently widely socialized in Indonesia.

The theory of restorative justice that has developed since 1970 until now is assumed to be the most recent shift from various models and mechanisms that work in the criminal justice system in handling criminal cases in the modern era (Effendi, 2014: 130). Restorative justice is a process to involve all possibilities, all related parties in certain violations, and a process to identify and explain threats, needs, and obligations in order to correct and put them properly in its place (Effendi, 2014: 131).

Based on the above descriptions, the government can use the concepts of restorative law enforcement to realize substantive justice in order to create an equal orientation between the perpetrators of crimes and the victims.

\section{Regulation of Legal Protection for Crime Victims in the Criminal Proce- dure Code (KUHAP)}

Before the enactment of Law No. 8 of 1981 concerning Criminal Procedure Law (KUHAP), the Het Herziene Indonesisch Reglement (HIR) had been used as a guideline for court proceedings in public justice in accordance with the provisions of the 1941 Staatblaad, Number 44. As a product of the Dutch inheritance law, certainly, every single provision was deliberately made to benefit the invaders, especially on the aspect of protecting human rights. On this basis, the procedural law (HIR) must be immediately changed and adjusted to the ideals of the Indonesian people that make and value Pancasila as the state foundation.

As a supreme thought by a citizen regarding the formal law, the Criminal Procedure Code has given a portion of attention to human rights. This is reflected in the process of investigation, examination in court, sentencing, until the implementation of the decision (Sahetapy, 1994: 9). The protection of an individual victim gets a portion of attention without ignoring the guidance of perpetrators in line with the theory of restorative justice.

In Article 77 jo Article 80 of the Criminal Procedure Code states that protection for the intended victim is a form of protection oriented to the interests of the victim. Victims are seen as one of the elements that must be considered in the process of resolving criminal cases in absolute terms as can be found in Article 77 jo Article 80 of the Criminal Procedure Code. The victim has room to exercise control over the investigator and/ or public prosecutor in the form of the right to file an objection to an act of terminating the investigation or prosecution, in his/her capacity as the third party. In addition, the victim can also make a pre-trial effort when the investigation or prosecution of a case is stopped. Both are forms of protection for victims. The right of control in question can provide guarantees that the criminal proceedings can be completed based on applicable legal provisions.

In addition, Article 98-101 of the Criminal Procedure Code also explains the restitution (claiming for compensation). The claim for compensation can be combined with a criminal case so that the victim can submit the request through a case of fusion (criminal-civil) mechanism. The content of this article is in accordance with Article 14c of the Indonesian Criminal Code, in terms of the judge's subjectivity in define the specific requirements for material compensation due to crimes that are caused as a result of criminal acts committed by the convicts. Merging civil and criminal cases allows victims to have two different positions in the justice system. On the one hand, he/she can be the witness of the victims; on the other hand, he/ she can function as the one who can claim for compensation for the suffering he/she embraces as a result of a criminal offense. Articles that the researchers mean can actually be a foothold for the state to give 
more attention to crime victims.

Finally, Article 134-136 of the Criminal Procedure Code states that the protection of victims is also reflected in the case of an autopsy. The family of the deceased has the right not to give permission to the police to conduct an autopsy. The three articles of the Criminal Procedure Code above are categorized as a form of protection for victims, bearing in mind that the autopsy issue is closely related to religious, customary, and norms of decency and politeness.

Although the KUHAP articles that have been described are the collection of articles oriented to victim protection, the researcher still finds that the principles of victim justice have not been fully reflected either in the dictum or in the explanation of the articles. The articles of Criminal Procedure Code which are oriented towards victims are still in theory and weak in terms of quantity when compared to articles containing protection of the rights of perpetrators of crimes. This condition confirms that the impact of the retributive justice theory that has been applied for many years is still very imprinted in law enforcement in Indonesia, where the portion of attention to the rights of perpetrators is prioritized over the rights of victims.

\section{The Arrangement of Legal Protection for Victims of Crimes according to Criminal Provisions Out of the Penal Code and Criminal Procedure Code}

The arrangements related to the protection of victims are also found in some special criminal law regulations. Some of the regulations include Law Number 7/ DRT/1955 concerning Economic Crimes, Law Number 23 of 1997 concerning Environmental Management (UUPLH), Law Number 5 of 1999 concerning Prohibition of Monopolistic Practices and Unfair Business Competition, and Law Number 8 of 1999 concerning Consumer Protection.

Law Number 7/DRT/1955 concerning Economic Crimes contains provisions by which the protection for victims is implemented in the form of "disciplinary measures", so that community losses to victims can be returned. This aspect is emphasized in Article 8 letter d:

\footnotetext{
"Requiring to do what is forgotten without rights, abolishing what is done without rights, and performing services to correct each other's consequences at the expense
}

of the convicts."

According to the researcher, the phrase "... correct each other's consequences all at the expense of the convicts ..." needs to be the concern of the government. Because the phrase can be a starting point that is oriented to the existence of victims in seeking claims for compensation (Mulyadi, 2007: 142). In this condition, the deterrent effect can be raised by imposing a criminal fine on the perpetrator as a result of his actions.

In addition to the above law, there is also Law Number 23 of 1997 concerning Environmental Management (UUPLH), which in Article 38 states that the public has the right to pursue a lawsuit based on group representation (class action). Then Article 47 states that criminal sanctions imposed on perpetrators of environmental offenses may be in the form of expropriation of profits derived from criminal actions, closure of all or part of the company, improvement due to criminal acts, obliging to do what is done without rights, and/or negating what conducted without rights; and/or put the company under forgiveness no later than 3 years. The above-mentioned six points of sanctions constitute a form of an effort to protect victims, especially in the third point. The restoration of the effects arising from environmental offenses is proof that the UUPLH contains provisions oriented to crime victims.

Furthermore, there are also special minimum provisions for the criminal cases which are stated in Law Number 5 of 1999 concerning the Prohibition of Monopolistic Practices and Unfair Business Competition. The product of the legislative body in the reform era can prevent the perpetrators of crime from administrative punishment that is too light. The payment of the amount of compensation money must be paid equivalent to the assets obtained from the offense that has been committed. For example, in Law Number 31 of 1999 jo Law Number 20 of 2001 concerning Eradication of Corruption, Article 18 paragraph (1) letter b also contains additional criminal provisions. The additional crime in this case is an attempt to protect victims.

In addition, Law No. 8/1999 concerning Consumer Protection also contains articles in favor of victims. In Article 19 of the law, it states that those who run businesses (or so-called the employers) are responsible for providing compensation for damage, 
pollution, or loss suffered by the consumers (victims) and the compensation does not abolish the possibility of criminal prosecution. In principle, this regulation also reflects the existence of efforts to protect victims, but again the nature of the protection is also not imperative, not real, indirect, and yet abstract and implicit.

It seems that the government needs to be firm in making laws and regulations so that its implementation is imperative and able to bring substantive justice in society.

\section{The Arrangement of Legal Protection for the Victims Caused by the Law- less Law Regarding the Protection of Witnesses and Victims}

Law Number 31 of 2014 concerning Amendment to Law Number 13 of 2006 concerning The Protection of Witnesses and Victims mandates that the government provide protection for witnesses and victims through authorized institutions. Article 1 point 8 states that:

"Protection is all efforts to fulfill the rights
and provide assistance to afford a sense of
security to witnesses and/or victims that must
be carried out by LPSK (the Witness and Victim
Protection Agency) or other institutions in
accordance with the provisions of this law."

The government protects witnesses and victims because both of them have an important role in the chain of the criminal justice system in Indonesia. Both witnesses and victims are people who hear, see, or experience a crime. The witness testimony and/or the victim's statement is one of the legal pieces of evidence in the judicial process. Testimony and information from both witnesses and victims can be one of the substantive judges' considerations in finding legal facts which then gives decisions in line with the values of justice.

The ratification of the Witness and Victim Protection Act can be said as a progressive step in the criminal law system in Indonesia because the regulation can be the basis for the formation of the Witness and Victim Protection Agency (LPSK). It is a task assigned to institutions to provide protection and rights to witnesses and victims at all stages of the criminal justice process. The presence of regulations and institutions in favor of witnesses and/or victims can provide a sense of security for both of them in seeking justice. Both witnesses and victims receive guarantees of freedom that are far from pressure, coercion, and intervention from other parties.

The phrase "victim" in this law can be defined in a broader sense, namely "People or groups of people who suffer physically, mentally, or emotionally, as well as suffer economic loss, or those who experience neglect, reduction and deprivation of rights essentially as a direct result of human rights violations" (Marwan \& Jimmy, 2009: 383).

Some of the rights granted to witnesses and victims are listed in Article 5 paragraph (1), namely: a) Obtain protection for personal security and property, as well as be free from threats relating to the testimony that will be or has been given; b) Participate in the process of selecting and determining forms of protection and security support; c) Give information without pressure; d) Get a translator; e) Free from entangling statements; f) Obtain information about the development of the case; g) Obtain information regarding court decisions; $h$ ) Knowing that the convict is acquitted; i) Getting a new identity; j) Obtaining a new residence; k) Obtain reimbursement of transportation costs as needed; I) Get legal advice; $m$ ) Obtain temporary living costs until the end of the protection period.

The right of protection is given to witnesses/victims in certain cases which include cases of criminal acts of corruption, narcotics, terrorism, as well as other criminal acts that harm and endanger the position of witnesses/victims. Victims of human rights violations, for example, besides receiving protection, they also have the right to receive medical assistance, rehabilitation, and psychosocial assistance by psychologists. In addition, the Law on Witness and Victim Protection also contains provisions on the right to post-traumatic psychological recovery (Article 6 letter $b$ ) and the right to compensation from the perpetrators as well as the right to restitution as victims (Article 7 paragraph [1]).

In addition to the three forms of protection above, witnesses and/or victims also still receive protection during the criminal justice process in the form of: a) They can give testimony without having to appear in court after obtaining permission from the judge (Article 9 paragraph [1]; and b) Witness and/or the victim, or the reporter cannot be prosecuted both criminal and civil over the testimony report that will be, is being, or has 
been given.

Witnesses and/or victims can give testimony without being present in court intended that in giving their testimony, they can do so through writing delivered before the court through the attorney with permission from the judge. Witnesses and/or victims cannot be prosecuted, both criminal and civil cases, for the testimony that will be, is being, or has been given. This aims at making the statements either from witnesses or victims in agreement with the facts of the trial and does not constitute factual refusal in front of the trial.

Based on the above data, the rules on the protection of witnesses and victims in Indonesia can be illustrated in figure 1 .

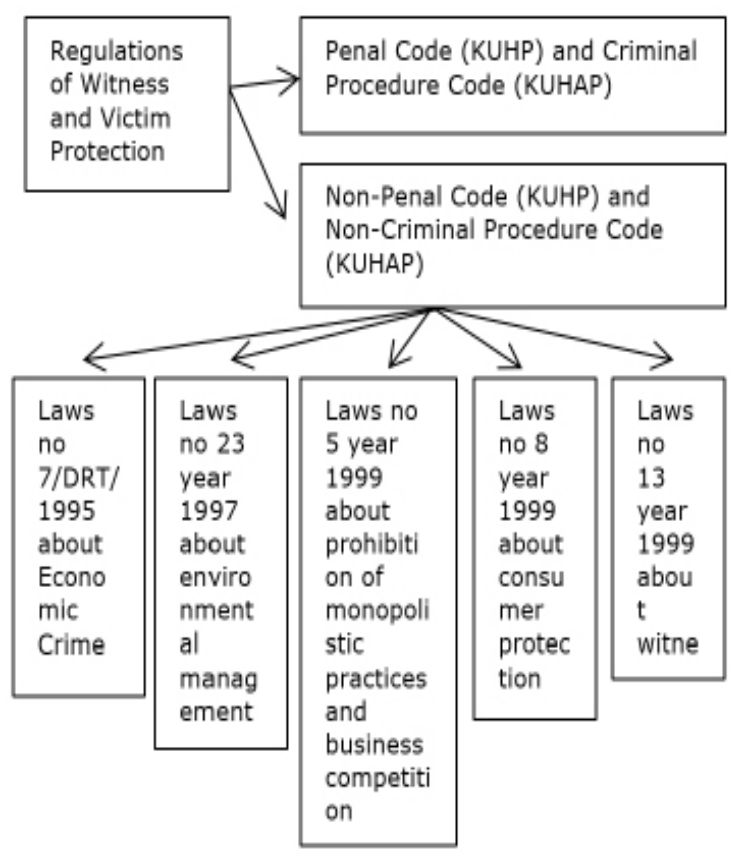

Figure 1. Regulations of the Witness and Victim Protection

\section{Factors That Influence the Imple- mentation of Protection for Crime Victims in Indonesia}

Based on the search, the Criminal Code and Criminal Procedure Code in general have a tendency to side with perpetrators of crime (offender oriented). This fact can be seen in the form of legal protection provided during the implementation of the Criminal Justice System starting from the investigation process, guarantee of consumption during detention, and the opportunity to get legal assistance in the trial process (Kenedi, 2020: 91). In addition, they have the right to take legal action on Appeals or Cassation and even
Judicial Review (PK). The legal protection also continued to the stage of being executed at the Penitentiary. In this stage, the offender gets full attention and facilities which include beds, medical care, recreation/entertainment, work education/training, as well as psychological/ spiritual guidance, and so on.

The reality above shows that the protection of the perpetrators gets a bigger portion than the protection of the victims. There is an impression that the criminal justice system has not given much attention to crime victims because the feelings of guilt remain after the criminal justice system focused more on the theory of retributive justice in the past.

Researcher, in this case, has found several factors that cause the portion of legal protection for victims to be ignored. The factors consist of regulatory factors, the participation of crime victims, and human resources of law enforcers, as well as supporting facilities and infrastructure factors.

The existing legislation does not yet reflect a unified legal order (unification) based on the national legal system even though the existence of legislation is crucial in achieving legal order according to the purpose of its formation. Moreover, the law is the main source of law, because all the various rules of law originate from statutory regulations. This assumption is reflected in the application of various different and less integrated legal arrangements. The difference is caused by various things, such as a) The existence of the rule of law derived from the Dutch colonial legal products that are still valid (KUHP, Civil Code, KUH Commerce, and several other ordinances); b) The validity of national legal products made after Indonesia's independence (both in the Old Order era, the New Order era, and the Reformation era); c) The validity of customary law in the community, especially in certain areas where customary law is used as the living law. Even some offenses that occur often end with customary peace institutions, even though this method is actually contrary to positive criminal law; e) The existence of Anglosaxon's legal rules, which are mixed with globalization in various fields, for example, in the economic field. As a result, law enforcement in Indonesia needs to use legal provisions that can meet the international legal order.

Based on the description above, there are various kinds of legal provisions that potentially cause problems in their 
implementation. Most law enforcers face a variety of legal options, namely resolving cases based on a positive legal order but lacking a sense of justice, security, and public order; or they might act out of the provisions of positive law by prioritizing rules from customary law. This happens because they consider customary law properly meets the wishes of the community.

Sometimes the failure of law enforcement in the world of justice is due to the lack of strict formulations in criminal law (Ibrahim, 2001: 14), which ultimately leads to the weakness of law enforcement. The absence of specific regulations governing certain crimes can obstruct law enforcement in Indonesia, in fact, law enforcement officials will experience difficulties in accusing the convicts.

This reality is similar to what happens to the protection for victims of crime. The laws governing the existing crime victims are still partial and their existence vary in-laws and regulations. As a consequence, the protection of crime victims can only be applied to certain crimes. In this case, the state still needs institutions that are responsible for handling the provision of protection even though the applicable regulations have textually mandated. The presence of these institutions can provide guarantees of convenience for people who seek protection.

The factor of participation of victims of crime also affects the portion of legal protection for victims. The low active participation of victims of crime in law enforcement reflects the low legal culture in Indonesia. As one of the objects of protection, the government must protect victims of crime for law enforcement. As an implication, it surely takes a lot of courage. The public - in this case including the victims - is required to be critical to legal practices while also having obedience and compliance with the law. The lack of victim awareness to report/complain about the crime that happened to him/her and the reluctance to be a witness are two types of anti-critical portraits of legal practices. Sometimes victims are reluctant to report/ complain due to the disgrace for the family, fear of threats/terror, shame, and other reasons. Likewise, rape victims refused to report because they felt ashamed. Yet these attitudes are potential to harm the victims, both in personal suffering and obstruction of the criminal justice process.

The domestic violence case can also be an example that represents the lack of participation of victims (Fatoni, 2014: 6). Such neglect seems to indicate a willingness to have long term suffering that can lead to stigma that domestic violence is natural to occur so as to close the interference of other parties in it. That is the reason why the protection of victims is not yet implemented.

Furthermore, human resource factors from law enforcement officers. Lack of expertise and skills of law enforcement officers in upholding the law can be an obstacle to the protection of victims in the perspective of law enforcement officials. The problem of human resources both in quality and quantity will certainly affect the service of protection for crime victims.

The minimum quality of the police officers can be found in terms of gaps formed between the police and the community while lacking the number of police-woman will certainly have an impact on the quality of services to the female victims.

In article 14 of the Witness and Victim Protection Law, it is stated that members of the LPSK consisting of police, prosecutors, the Ministry of Law and Human Rights, Academics, Advocates, or Non-Governmental Organizations (NGOs) are only in certain cities, not covering the entire region in Indonesia even though crime victims are widespread throughout the country. The lack of quantity can also be seen from the lack of female police officers who have the qualifications as doctors or psychiatrists/psychologists who are placed in women's service units.

The last factors are the supporting facilities and infrastructure. Supporting facilities and infrastructure is an urgent need in an effort to protect victims. It is said so because inadequate facilities and infrastructure will certainly have implications for the quality of protection. For example, when wanting to implement the mandate of Article 5 paragraph (1) letter $j$ of Law Number 13 the Year 2006 which states that a victim-witness has the right to obtain a new residence. The phrase "new residence" in the intended article is interpreted as a certain place that is temporary and is considered safe for the victim. The problem in the implementation of the mandate of the law that arises is the issue related to the one who is required to prepare the place. Not to mention the financing system and the duration of placement in the "new residence". The article is somehow still unclear, so it requires real 
explanations.

Another problem of facilities is found in rape cases. The government is required to prepare a special service room separated from the usual inspection room wherein the room must create a sense of comfort and familiarity to mental condition. Besides, the room can also be used for the investigation carried out by policewomen, doctors, psychiatrists, and psychologists. It is unfortunate that there are still inadequate services for both rape victims and victims of narcotics abuse.

The four factors mentioned above can be a concern for the government so that the improvement can be made to all elements with the aim of creating protection for crime victims in accordance with the mandate of the law and the fulfillment toward a sense of substantive justice.

\section{Conclusions}

The criminal law system in Indonesia pays more attention to the rights of perpetrators of crimes, not in favor of victims (criminal oriented) as the implications of retributive justice theory application that does not favor the perpetrators of crime. At the level of formal law, the portion of protection for perpetrators of crime is more than the legal protection given to crime victims. Although there are several legislative legal products that regulate legal protection for witnesses and victims of crime, the intended legal protection has not yet received the portion of attention that is in accordance with the mandate of substantive justice.

The position of the victim in the criminal justice process is considered only as a complement or only a small element in an effort of the search for material truth. The rights of protection for victims contained in the legislative legal product cannot be said to be equal with the rights possessed by the perpetrators of crime. The victim-oriented provisions are still partial and unclear even though the world is intensively applying the theory of retributive justice.

The summit factor of the articles of the law and the minimum participation of victims are two things that hinder the realization of legal protection for witnesses and victims in Indonesia. The unclear meaning of some words in an article of the existing law and the victim's lack of understanding of their rights are the causes of the complication endured by the victims where there are the miss-capability of human resources owned by government officials and the lack of infrastructure that can support the establishment of substantive justice. The improvements to the four factors must be immediately carried out by the government in order to realize the protection of victims in accordance with the mandate of the law to fulfill a sense of justice.

\section{Acknowledgment}

I thank the Head of the Witness and Victim Protection (LPSK) Agency of the Republic of Indonesia.

\section{References}

Angkasa. (2008). Bahan Ajar Viktimologi dalam Mata Kuliah Viktomologi, Bengkulu: Universitas Hazairin.

Atmasasmita, R. 1992). Masalah Santunan terhadap Korban Tindak Pidana, Jakarta: BPHP Departemen Kehakiman Republik Indonesia.

Demir, M. (2018). "The Perceived Effect of a Witness Security Program on Willingness to Testify", International Criminal Justice Review, Vol. 28, Issue 1, USA: Georgia State University.

Doak, J. (2017). "The Victim and the Criminal Trial: A Survey of Recent Trends in Regional and International Tribunals", Law School Journal, Ireland: University of Ulster.

Effendi, M. (2014). Teori Hukum. Ciputat: Referensi.

Fatoni, S. (2014). "Urgensifitas Perlindungan Saksi dan Korban dalam Mengungkap Kasus Kekerasan dalam Rumah Tangga", Mimbar Hukum, Vol. 26, No. 3. Yogyakarta: Fakultas Hukum Universitas Gadjah Mada (UGM).

Fuady, M. dan Sylvia Laura. (2015). Hak Asasi Tersangka Pidana. Jakarta: Kencana.

Ibrahim, M. (2001). Penegak Supermasi Hukum di Indonesia: Pemikiran Reflektif tentang Merosotnya Wibawa Hukum, Jakarta: Asy-Syir'ah.

Ismail. (2016). "Perlindungan Hukum terhadap Saksi Pengungkap Fakta (Whistle Blower) dalam Perkara Pidana berdasarkan Undang Undang Nomor 13 Tahun 2006 tentang Perlindungan Saksi dan Korban", Jurnal IImu Hukum Legal Opinion Edisi I, Volume 4.

Iswanto dan Angkasa. (2007). Viktimologi, Purwokerto: Fakultas Hukum Univeritas 
Jenderal Sudirman.

Kenedi, J. (2017). Kebijakan Hukum Pidana (Penal Policy) dalam Sistem Penegakan Hukum di Indonesia. Yogyakarta: Pustaka Pelajar.

Kenedi, J. (2020). Perlindungan Saksi dan Korban: Studi Perlindungan Hukum Korban Kejahatan dalam Sistem Peradilan di Indonesia. Yogyakarta: Pustaka Pelajar.

Khan, A. (2012). "Victims and Witnesses Protection: A Commonwealth Perception", Commonwealth Bulletin, Vol. 39, issue 1, $2^{\text {nd }}$ Regional Association of Prosecutors (IAP) of The Conference Africa-Indian Ocean Region, Mauritius.

Marwan dan Jimmy. (2009). Kamus Hukum. Surabaya: Reality Publisher.

Moeljatno. (2015). Asas-asas Hukum Pidana. Jakarta: Rineka Cipta.

Mulyadi, L. (2007). Kapita Selekta Hukum Pidana, Kriminologi, dan Victimologi, Jakarta: Djambatan.

Rifai, E. (1994). Masalah Tidak Efektifnya Penegak Hukum, Semarang: Universitas Diponegoro.

Sahetapy, E. (1994) Citra dan Kewibawaan Hukum Pengadilan, Surabaya: UNTAG Press.

Salman, O. dan Susanto, A. (2013). Teori Hukum. Bandung: Refika Aditama.

Soekanto, S. dan Mamudji, S. (2012). Penelitian Hukum Normatif: Suatu Tinjauan Singkat, Jakarta: PT. RajaGrafindo Persada.
Soesilo, R. (1991). Kitab Undang Undang Hukum Pidana (KUHP) Beserta Komentarkomenternya Lengkap Pasal demi Pasal, Bogor: Poleitia.

Sulistia, T., dan A. Zurnetti. (2012). Hukum Pidana: Horizon Baru Pasca Reformasi. Jakarta: Rajawali Pers.

Undang Undang Nomor 13 Tahun 2006 tentang Perlindungan Saksi dan Korban.

Undang Undang Nomor 20 Tahun 2001 tentang Pemberantasan Tindak Pidana Korupsi

Undang Undang Nomor 23 Tahun 1997 tentang Pengelolaan Lingkungan Hidup

Undang Undang Nomor 31 Tahun 2014 tentang Perubahan Undang Undang Nomor 13 Tahun 2006 tentang Perlindungan Saksi dan Korban.

Undang Undang Nomor 48 Tahun 2009 tentang Kekuasaan Kehakiman.

Undang Undang Nomor 5 Tahun 1999 tentang Larangan Praktik Monopoli dan Persaingan Usaha Tidak Sehat.

Undang Undang Nomor 7/DRT/1955 tentang Tindak Pidana Ekonomi.

Undang Undang Nomor 8 Tahun 1981 tentang Hukum Acara Pidana.

Undang Undang Nomor 8 Tahun 1999 tentang Perlindungan Konsumen.

Welch, Tim., dkk. (2011). "Witness Anonymity at The International Criminal Court: Due Process for Defendants, Witnesses or both?", The Denning Law Journal, Vol 23. 